\title{
MENTAL TOUGHNESS OF PON ATHLETES OF SPECIAL REGION OF YOGYAKARTA, INDONESIA
}

\author{
Anas Ardiansyah, \\ Dimyati ${ }^{i}$ \\ Department of Sport Science, \\ Yogyakarta State University, \\ Yogyakarta, Indonesia
}

\begin{abstract}
:
This research aims to determine: (1) differences in mental toughness of the PON athletes of Special Region of Yogyakarta based on each branch of sport, (2) differences in mental toughness of the PON athletes of Special Region of Yogyakarta based on the category of individual and team sports. The type of this research was a descriptive comparative study. The research population was the PON athletes of Special Region of Yogyakarta who would compete in the National Sports Week competition in Papua totaling 135 athletes from 23 branches of sports. The sampling technique used purposive sampling. The criteria in determining this sample included: (1) PON athletes of Special Region of Yogyakarta who would take part in the National Sports Week competition in Papua, (2) were willing to be a sample, and (3) fully filled out the instrument provided by the researcher. Based on this criteria, there were 100 athletes from 14 branches of sports. The instrument used Mental Toughness Questionaire (MTQ). The MTQ validity index was at $0.310-0.560$ with a reliability coefficient at 0.862 . The data analysis technique used One Way Anova and Independent Sample Test. The results show that: (1) there is a significant difference in the mental toughness of the PON athletes of Special Region of Yogyakarta based on each branch of sport, with $p>0.005$. The mental toughness of pencak silat and gliding athletes is better than athletes from other sports. (2) There is a significant difference in the mental toughness of the PON athletes of Special Region of Yogyakarta based on the category of individual and team sports, with $p>0.005$. The mental toughness of the athletes in individual sports is better than those in team sports.
\end{abstract}

Keywords: mental toughness, individual sports, team, PON athletes of Special Region of Yogyakarta

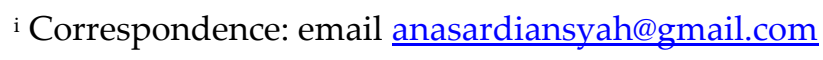




\section{Introduction}

The National Sports Week (PON) which is held every four years is the biggest multievent sporting event at the national level involving sports competitions from 35 provinces throughout Indonesia. The first PON which was held in Solo 1948 tended to be more politically nuanced, aimed at the international community that despite the atmosphere of the revolution against the Dutch, the Indonesian nation was able to successfully organize the sporting event. However, along with the development and progress of sports at an increasingly competitive international level, all have an impact on shifting the goals of PON. The purpose of PON is no longer just a way to unify the nation, but also as a means of fostering and searching for regional athletes who are prepared for national sports athletes to achieve international sports achievements.

With that being said, the implementation of PON in the post-reform era is very far from the ideal goal, which was originally a means of coaching tiered sports for regional athletes at the national level. PON more reflects the show of financial strength and prestige of the Governor as the head of the Region, so that "by all means" for the gold medal to be the best in PON. This phenomenon occurred starting with the implementation of PON XVI in East Kalimantan (2004), PON X VII in 2008 in South Sumatra (2008), and finally the XIX PON which was held in West Java (2016) where bonus wars and buying and selling of athletes between regions were very rampant. Likewise, ahead of the 2021 PON XX, which is planned to be held in Papua. The bonus war offered by local government officials, in this case, is beyond reason. As planned by the Governor of DKI Ahok at that time, which would give a bonus of Rp. 2 billion for Jakarta athletes who managed to get gold medals at PON XIX West Java. Other provinces, such as East Java, also did the same thing where the provincial government promised a bonus of IDR. 200 million for athletes who won gold medals at the 2016 PON in West Java ("Ahok's intention to give a bonus of IDR. 2 billion for 2016 PON Gold Winners", Koran Sindo, February 10, 2016).

The policy of giving bonuses that are fantastic and beyond reason is unhealthy because it will have a bad impact on sports development in the future. Many negative impacts may arise due to excessive bonus offers, one of which is the threat of coaching in developing areas where athletes may choose rich areas. For a province such as the Special Region of Yogyakarta (DIY), it is impossible to implement such a bonus policy. This is not solely due to budget constraints, but KONI DIY prefers sports coaching that relies on the potential of human resources (HR) as optimally as possible. This effort, for example, is the involvement of academics and sports scientists from various universities (PT) to participate in the process of coaching the achievements of DIY athletes in preparation for the 2021 PON XX in Papua (Interview, Head of Coaching and Achievement, KONI DIY, 2020).

The policies taken by the KONI DIY management as mentioned above are in line with what Romas said (2019: 1). He explained several components that determine the achievement of optimal performance in sports, namely the state of sports facilities, competitions, athlete psychology, athlete abilities and skills, athlete's physical ability, 
body constitution, and tactical/strategic abilities. The trainers believe that no less than $50 \%$ of success in sports is determined by mental factors, even for sports such as golf, tennis, and figure skating which has mental factors even reaching $80 \%$ to $90 \%$ (Weinberg \& Gould, 2015 in Nopiyanto, Dimyati, \& Dongoran, 2019: 28).

Many coaches do not have knowledge of the psychological skills of players as well as their application in the form of mental skills training (Freitas, Dias, \& Fonseca, 2013: 81). Likewise, sports coaches in Indonesia have not realized the importance of this mental aspect in coaching sports achievements. It is a very rare thing; it can even be said that no coach specifically applies mental skills training to his players. This problem is no different from the condition of DIY PON athletes who need a psychological role to achieve maximum performance when competing.

With those being said, it is known that the biggest main factor to achieve a good level of performance is the player's self. There is a term that in a match, the psychological aspect has $80 \%$ influence while $20 \%$ covers other aspects. Other research findings also report that psychological aspects contribute more than $50 \%$ to the success of athletes when competing (Setiawan, Patah, Baptista, Winarno, Sabino, \& Amalia. 2020: 159). Mental problems referred to in this case can have a positive or negative influence. For example, a player with good physical and technical qualities, but easily provoked and unable to control his emotions because of the rough play of the opposing player, will result in their concentration dropping where the abilities are given will also not be optimal.

On the other hand, if a player has a good mentality, and encounters a situation where he is confronted by an opposing player, the player will easily stay focused on the game. The good mental problems must be owned by DIY PON athletes. Athletes who can compete at a higher level, of course, have higher demands for abilities and must be possessed as an athlete. Athletes will be increasingly required to have improved technical, physical, and mental abilities, better than before. If an athlete is not able to cope with these demands, then he will not be able to show his best performance.

Therefore, athletes also need to make mental preparations to develop their athletes' cognitive, emotional, and behavioral strategies so that they are able to direct their emotions and cognitive abilcands maximum performance (Khoirunnisa \& Jannah, 2014: 2). Mental toughness is defined as a personal capacity that can create and improve performance both subjectively and objectively even under challenges, overcoming stress, anxiety, and despair related to competitive situations (Nugraha, Salman, Pratama, Al Fayed, Ikhram, Bahrun, \& Nurlifiana, 2020: 123). Mental toughness is often considered as a personality, so it is hoped that it can be applied in various aspects of social life, including in competitive situations (Hardiansyah \& Masturah, 2019: 239). Athletes who have high mental toughness are reflected in an athlete's ability to cope with stress and anxiety associated with high-pressure competitive situations (Jones, 2002: 206).

Individuals who have high anxiety require intervention or training to develop good mental toughness to consistently maintain concentration and motivation, so they are not easily influenced by competitive situations. The higher a person's mental toughness, the lower the level of anxiety they have. The more capable an athlete is to be 
positive about pressure, the lower his anxiety in facing competition (Hardiansyah \& Masturah, 2019: 239). Raynadi, Rachmah, and Akbar (2016: 150) say that one of the important components that can determine the success of athletes in the arena of competition is mental toughness. Aryanto and Larasati (2019: 307) stated that athletes with high mental toughness can manage potential negative emotions that can be debilitating when there is pressure; Athletes will also have more adaptive subjective interpretations of experiences that lead to negative emotions, such as competing for anxiety, which have an impact on the achievement of an athlete's goals. It also makes the discussion of mental toughness interesting.

Mental toughness facilitates a psychological advantage for sports players. This helps individuals perform better than their opponents and strive to succeed under pressure (Ruparel, 2020: 1). Working with elite athletes means using the term mental toughness to denote stress tolerance and maximum performance; explicitly, the ability to consistently perform toward a person's various skills and talents regardless of circumstances. Although mental toughness originated in the psychology of sport, it has since evolved into a pervasive psychological construct associated with successful performance in a variety of applied settings (education, work, health, and others) (Drinkwater, Dagnall, Denovan, \& Parker, 2019: 269). Jones (2002: 205-206) states that mentally tough athletes respond in a variety of ways that allow them to remain relaxed, calm, and energized because they have learned to develop two skills; first, the ability to increase their flow of positive energy (i.e., use energy positively) in crises and adversity, and, second, to think in a certain way so that they have the right attitude about problems, pressures, mistakes, and competition. Furthermore, mental toughness has also been described as a personality trait and state of mind.

Knowledge related to mental toughness training is an important thing that needs to be understood by coaches to raise awareness that teaching mental toughness skills is as important as teaching technical and physical skills to their players. A small number of coaches in terms of daily coaching are known to have applied mental skills training, both to players as individuals and teams, but are only less aware of it (Dimyati, 2018: 187). In athletes, mental toughness is a factor that greatly determines their psychological readiness, both during training and during matches. If the athlete's psychological condition is good, then the opportunity to show the best will also be owned. Mental toughness is one of the most important psychological constructs that underlie sports performance. Sports mental toughness is defined as the superior mental quality of an athlete (Kalinin, Balazsi, \& Pentek, 2019: 71).

The studies and literature review as described above put more emphasis on athletes abroad. Meanwhile, there has been no study on the mentality of PON athletes in Yogyakarta which is associated with the mental toughness of athletes. Thus, the dimensions of the mental toughness of DIY PON athletes differ from each other in terms of various branches and teams of achievement participants. Knowledge and understanding of the mental toughness of athletes related to supporting the coaching and performance of PON athletes in DIY are very important for coaches and sports coaches to know to optimize the performance of athletes in PON. 
To the author's knowledge, until now there is no data related to the mental toughness of DIY PON athletes. Likewise with an in-depth study of how the mental toughness of DIY PON athletes, in terms of individual and team sports. The basic difference between individual and group athletes is seen in the way they compete. Individual athletes put more emphasis on working alone/independently, while a sense of cooperation is more emphasized on group athletes. One of these points is one of the considerations for the differences between individual and group athletes (Murdiansyah, 2015: 135-136).

Research by Golby and Sheard (2004: 939) suggests that international athletes, super league, and first division have similarities in the ability to control negative energy, imagery control, and visualization, where these abilities are included in the aspect of mental toughness. Lopez and Juan's research, (2015) also found a significant difference in mental toughness between men and women. Male athletes have five advantages which are attributes of mental toughness compared to female athletes. The five attributes include self-confidence, visual and imagery control, level of motivation, positive energy, and attitude control.

Another finding comes from Killy, Nieuwerburgh, and Clough (2017: 112) who found the inhibiting factors for mental toughness, which include feelings of uncertainty about the actions taken. Mental toughness is widely recognized as a fundamental attribute for achieving success in sport. Mentally, tough athletes will maintain a level of performance in the face of adversity; view pressure as a challenge and a catalyst for prosperity; and maintain emotional, cognitive, and behavioral control despite existing situational pressures (Cowden, 2017: 1). Mental toughness is one of the more important determinants of performance at the peak of achievement (Sajjan, 2018: 157). The contribution between mental toughness and competitive anxiety has a percentage of $45 \%$, while the remaining 55\% is determined by other variables (Algani, Yuniardi, \& Masturah, 2018: 97). Critical situations when competing in the field will be increasingly felt by athletes in individual body contact sports, such as martial arts.

The results of the study of Schurr (1979) cited by Indrayogi (2018: 8) found that there were differences in personality dimensions between individual and team sports athletes which showed that athletes who were involved and involved themselves in team sports tended to show lower levels of internalization of anxiety and were more independent, open and objective. However, athletes in team sports tend to be less imaginative-sensitive than individual athletes. Based on the background that has been stated above, the researchers are interested in conducting a study with the title "Mental Toughness of PON Athletes in the Special Region of Yogyakarta".

\section{Method}

\subsection{Types of research}

The type of research used in this research is comparative descriptive research. Comparative research according to Sugiyono (2015: 54) is a study that compares the state of one or more variables in two or more different samples, or at two different times. 


\subsection{Target/Research subject}

The population in this study were PON DIY athletes who will compete in the National Sports Week competition in Papua totaling 135 athletes spread over 23 sports for PON DIY athletes. Sampling in this study was conducted by purposive sampling. The criteria in determining this sample include: (1) DIY PON athletes who will compete in the National Sports Week competition in Papua, (2) willing to be a sample, and (3) filling out the instrument provided by the researcher in full. If they do not meet any of these conditions/criteria, the respondent will fall into the sample. Based on these criteria, those who met the research sample obtained a sample of 100 athletes from 14 sports. Furthermore, it will be differentiated based on individual sports totaling 52 athletes and team sports 48 athletes.

\subsection{Research variable}

The variable that will be examined in this study is the mental toughness of the athletes of the PON Special Region of Yogyakarta. Mental toughness is an attitude or selfassessment of positive emotional reactions, especially athletes to overcome obstacles, difficulties, even pressure, to maintain concentration and motivation which is a determination of positive energy to achieve a goal in surviving throughout the game.

\subsection{Data collection instruments and techniques}

The instrument used to measure the mental toughness of athletes is the Mental Toughness Questionaire (MTQ) which was adapted from (Goldberg, 1998). In addition, an instrument developed by an expert in Sports Psychology, Sheard from York St John University, England (LeUnes, 2011) will be used. The scale consists of 14 items with 5 components of mental toughness, including Confidence, Firmness, and Control. MTQ validity index, in this case, is $0.310-0.560$ with a reliability coefficient of 0.862 . The Mental Toughness Questionnaire (MTQ) instrument lattice will be explained.

\subsection{Data analysis technique}

The data analysis in this study was performed by using the application of Software Statistical Product and Service Solutions (SPSS) version 23.0. Meanwhile, the first hypothesis was tested by using Anova One Way and a t-test (Budiwanto, 2017: 292).

\section{Results}

The results of this study are used to answer the hypotheses in the previous chapter. The instrument used is the Mental Toughness Questionaire (MTQ) scale which was adapted (Goldberg, 1998). The scale consists of 14 items with 5 components. Descriptive statistics on the mental toughness of PON athletes from the Special Region of Yogyakarta are presented in Table 1: 
Table 1: Descriptive Statistics of Mental Toughness of PON Athletes, Special Region of Yogyakarta

\begin{tabular}{|l|c|c|c|c|}
\hline Sport & N & Mean & SD & Description \\
\hline Archery & 16 & 46,38 & 2,33 & High \\
\hline Pencak Silat (Martial Art) & 11 & 52,91 & 2,02 & Very High \\
\hline Kite Flying & 6 & 53,00 & 2,45 & Very High \\
\hline Skates & 5 & 48,20 & 6,42 & Very High \\
\hline Wushu & 3 & 41,67 & 4,04 & High \\
\hline Judo & 2 & 49,00 & 1,41 & Very High \\
\hline Athletic & 2 & 41,00 & 2,83 & High \\
\hline Rock Climbing & 3 & 47,33 & 2,52 & Very High \\
\hline Bodybuilding & 2 & 43,50 & 4,95 & High \\
\hline Chest & 2 & 44,00 & 2,83 & High \\
\hline Rugby & 28 & 43,57 & 4,18 & High \\
\hline Water Polo & 12 & 40,00 & 6,24 & High \\
\hline Sand Volleyball & 8 & 41,25 & 5,60 & High \\
\hline
\end{tabular}

When presented in the form of a line diagram, the mental toughness of the Yogyakarta Special Region PON athletes based on each sport can be presented as shown in Figure 1:

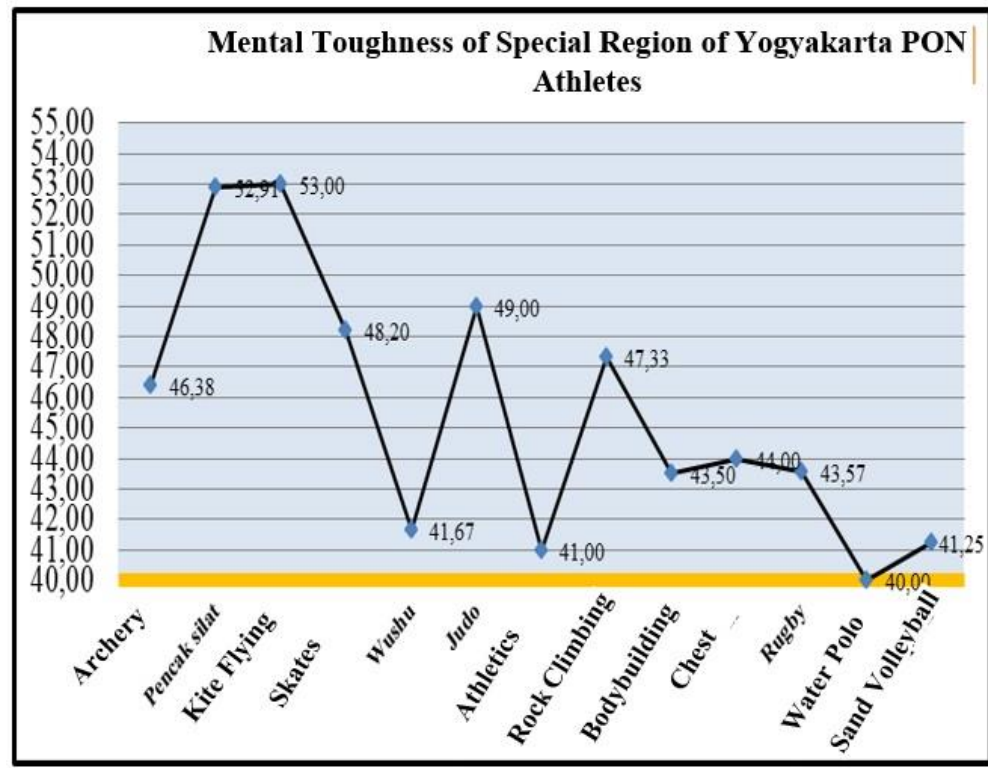

Figure 1: Line Diagram of Mental Toughness of PON Athletes from the Special Region of Yogyakarta

The statistical description of the mental toughness of PON athletes from the Special Region of Yogyakarta based on individual and team sports is presented in Table 2. 
Table 2: Descriptive Statistics of Mental Toughness by Individual Sports and Teams

\begin{tabular}{|l|c|c|c|c|}
\hline Sport & N & Mean & SD & Description \\
\hline Individual & 52 & 48,17 & 4,76 & Very High \\
\hline Group & 48 & 42,29 & 5,13 & High \\
\hline
\end{tabular}

The mental toughness of PON athletes of the Special Region of Yogyakarta based on individual and team sports when presented in the form of a bar chart is shown in Figure 2:

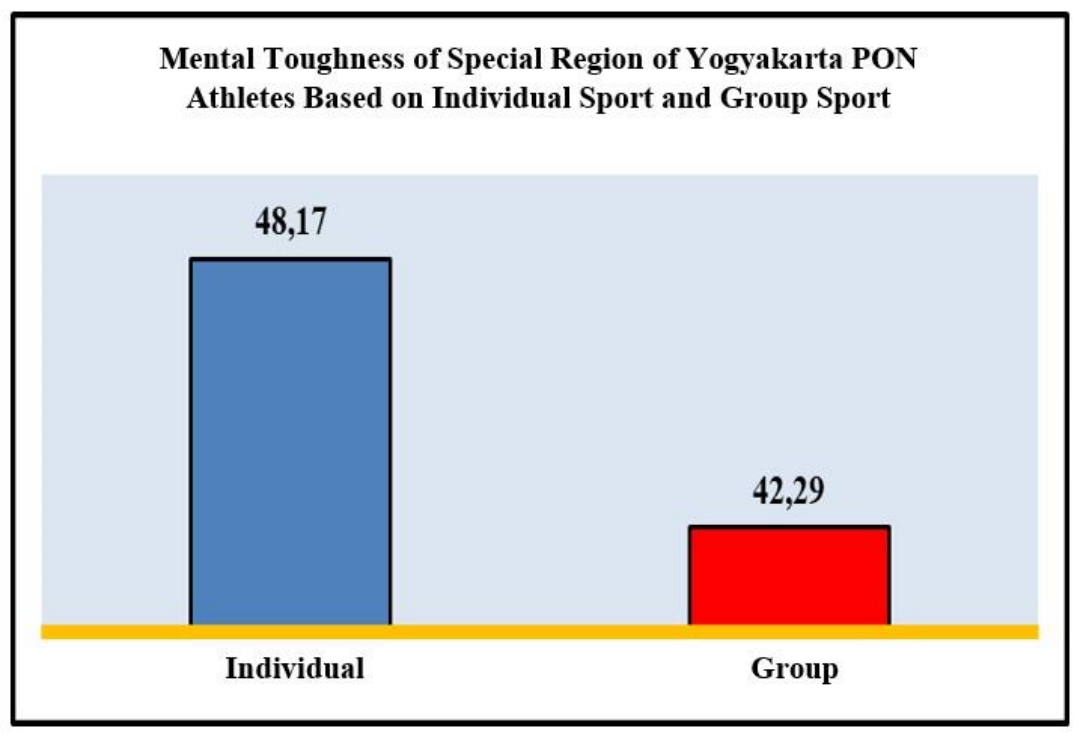

Figure 2: Bar Diagram of Mental Toughness of PON Athletes, Special Region of Yogyakarta

\subsection{Prerequisite test results}

\subsubsection{Normality test}

The data normality test in this study was conducted by using the Shapiro-Wilk method. The summary of data is presented in Table 3.

From the results of Table 3 above, it can be seen that the data on the mental toughness of PON athletes from the Special Region of Yogyakarta based on individual and team sports has a p-value (sig.) $>0.05$, so the data is normally distributed.

\subsubsection{Homogeneity test}

A homogeneity test was conducted to test the equality of several samples, whether it is homogeneous or not. The results of the homogeneity test are presented in Table 3.

Table 3: Homogeneity Test

\begin{tabular}{|l|c|c|}
\hline Group & sig & Description \\
\hline Individual Sport and Group Sport & 0,603 & Homogeneous \\
\hline
\end{tabular}

Based on the data presented in Table 3, it is known that the value of sig. the mental toughness of PON athletes from the Special Region of Yogyakarta based on individual and team sports is $>0.05$ so the data is said to be homogeneous. 


\subsection{Hypothesis test results}

The first hypothesis in this study is "There is a significant difference related to the mental toughness of DIY PON athletes based on each sport". The results of the analysis obtained using the One Way Anova test are presented in Table 4.

Table 4: One Way Anova Test Results

\begin{tabular}{|l|c|c|c|}
\hline & Sum of Squares & F & Sig. \\
\hline Between Groups & 1731,100 & \multirow{2}{*}{8,237} & \multirow{2}{*}{0,000} \\
\hline Within Groups & 1523,650 & & \\
\hline Total & 3254,750 & & \\
\hline
\end{tabular}

Knowing the results of the One Way Anova test as presented in Table 4 above, it can be seen that the significance value of $p$ is 0.000 and the calculated $F$ value is 8.237 . Because the significance value of $\mathrm{p}$ is $0.000<0.05$, this indicates that $\mathrm{H}_{0}$ is rejected. In other words, the research hypothesis which states that "There is a significant difference in the mental toughness of PON DIY athletes based on each sport", has been proven.

The second hypothesis in this study is "There is a significant difference in the mental toughness of DIY PON athletes based on individual and team sports". The results of the analysis using the t-test are presented in Table 5:

Table 5: The Differences in Mental Toughness of PON DIY Athletes based on Individual and Team Sports

\begin{tabular}{|l|c|c|c|}
\hline Sports & $\boldsymbol{t}_{\text {hitung }}$ & $\boldsymbol{t}_{\text {tabel (df 98) }}$ & sig \\
\cline { 1 - 2 } Individual & 5,948 & 1,984 & 0,000 \\
\cline { 1 - 1 } Team & 5 & \\
\hline
\end{tabular}

From the results of the t-test in Table 5 above, it can be seen that the $t_{\text {count }}$ is 5.948 and the $t_{\text {table }}(\mathrm{df} 98.5 \%$ ) is 1.9484 with a p significance value of 0.000 . Because the $t$ count is 5.948> $\mathrm{t}$ table is 1.984 , and the significance value is $0.000<0.05$, this result shows a significant difference. Based on the results of the analysis, the alternative hypothesis (Ha) which reads "There is a significant difference in the mental toughness of DIY PON athletes based on individual and team sports", has been proven. The difference in mental toughness of DIY PON athletes based on individual and team sports is 5.88. This shows that the mental toughness of individual sports PON DIY athletes is better than team sports.

\section{Discussion}

\subsection{Differences in mental toughness of DIY PON athletes based on each sport branches} The results of the study found significant differences related to the mental toughness of PON DIY athletes based on each sport. The mental toughness of Pencak silat and kite flying was found to be better than other sports. Pencak Silat athletes are expected to have high emotional reactions in competing. Sukadiyanto (2006: 2) argues that emotional reactions can be defined as changes in the level of excitement that can facilitate or hinder a person's desire to behave or act. Following this explanation, the mental condition is 
very important and needs to be prepared as well as possible which does not even rule out the possibility that mental condition is also a determining factor in matches. Therefore, a Pencak Silat athlete needs to have good mental preparation so that it will be easier to overcome disorders such as anxiety that can affect performance in matches. Newland, Newton, Finch, Harbke, \& Podlog (2014) stated that mental toughness was identified in $82 \%$ of wrestling coaches as the most important prerequisite for competitive success.

Cox and Liu (in Dimyati, Herwin, \& Hastuti, 2013: 145) found that elite athletes have good self-confidence so they can control anxiety. Several psychological aspects that are necessary and influential on the appearance of martial arts sports (Pencak silat, tae kwo do, and others) are concentration, anticipation, emotional control, self-control, selfconfidence, and fighting power (Dosil, 2006 in Dimyati, Herwin, \& Hastuti, 2013: 145). Dimyati, Herwin, and Hastuti (2013: 145) say that an optimistic attitude is important for martial arts athletes because of its impact on increasing fighting power, concentration, and focus on attention.

Mental toughness can provide a sense of relaxation, calm, and enthusiasm so that athletes are still able to develop two skills, namely positive responses such as perceiving to reduce difficulties and thinking about attitudes, even ignoring problems, mistakes, pressure, and competition in a match (Jones, 2010 in Retnoningsasy \& Jannah, 2020: 10). Mental toughness is seen as an important element that can shape an athlete to succeed in becoming a champion. Mental toughness makes athletes confident and always ready to face the competition and accept whatever the outcome of the match is. If an athlete already has good mental toughness, it will be possible for him to get achievements that continue to increase and even maintain their achievements (Nurhuda \& Jannah, 2018: 2). Clough, et al. (in Retnoningsasy and Jannah, 2020: 10) explains that if an athlete's mental toughness is low, then when faced with situations that tend to be stressful, he will cause negative reactions, such as nervousness when competing, unstable emotions, loss of concentration and behavior beyond internal control of athlete. In addition, there is another opinion that says that if the athlete's mental toughness is high, then the athlete will be able to display positive reactions, such as being calm despite pressure from supporters, maintaining the focus point even though the score is far behind the opponent, and increasing motivation due to tension competition also increases (Yanti \& Jannah, 2017 in Retnoningsasy and Jannah, 2020: 10).

Broadly speaking, it can be said that athletes who have a high level of mental toughness have a better ability to reduce sports anxiety and have good self-control in dealing with pressure. This can be proven along with the increase in the skills of an athlete which is accompanied by an increase in the level of mental toughness possessed (Jones, Hanton, \& Connaughton, 2007: 144). The results of research from Raynadi, Rachmah, and Akbar (2016: 150) reveal that the relationship between mental toughness and competition anxiety in Pencak silat athletes is contradictory. In other words, the higher the mental toughness means the lower the competition anxiety, and vice versa where the lower the mental toughness level, the higher the competition anxiety level. 


\subsection{Differences in mental toughness of DIY PON athletes based on each sport branches}

From the research that has been done, it was found that there were significant differences related to the mental toughness of PON DIY athletes based on individual and team sports. The mental toughness of individual sports PON DIY athletes was found to be better than team sports. The fundamental difference between individual and group athletes, in this case, is in terms of how to compete. Individual athletes place more emphasis on working alone/independently, while group athletes emphasize a sense of cooperation. These differences are one of the considerations for the differences in individual and group athletes (Murdiansyah, 2015).

Research results obtained by Ilyasi \& Salehian (2011: 527) states that individually, athletes have higher levels of extraversion, openness, and sincerity than team athletes. Individual sports athletes have a higher conscientiousness level than team athletes. This is supported by the research of Nia and Besharat (2010: 808-812) which found that individual sports athletes had significantly higher conscientiousness than team sports athletes. In the aspect of conscientiousness, it is precisely the individual sports athletes who are higher. This is because the individual sporting environment has shaped him into a person who is organized, organized, hardworking, highly disciplined, meticulous, full of ambition, and stubborn in his stance. In contrast, team sports athletes tend to be less persistent, reckless, less determined, so that individual sports athletes can be said to be more reliable than team sports athletes (Feist \& Feist, 2008).

Sinulingga and Hardinoto (2014: 184) find that sports in the United States are experiencing a crisis. The reason is that in addition to sports experiences that damage character development, also because character building is not inherent in sports. Athletes who engage in team sports tend to have lower scores and have a negative relationship with involvement in sports and character development. Especially in the professional sport of golf, good and bad appearance is largely determined by psychological factors such as anxiety, somatic, cognitive anxiety, attention control, and emotional control. Research on personality aspects which is a more general part of psychological aspects shows personality differences between wrestlers, swimmers, baseball athletes, basketball athletes, and football athletes (Gunarsa, 2008 in Dimyati, Herwin, \& Hastuti, 2013: 156 ). In line with this theme, Singer (in Cox, 2002 in Dimyati, Herwin, \& Hastuti, 2013: 156) said that based on observations made of baseball athletes and tennis athletes, it was found that there were differences related to personality aspects in team sports athletes with individual sports athletes. The results of other studies conducted on the sports of football, wrestling, gymnastics, and karate, showed that the personality characteristics of these athletes were different from one another (Dimyati, Herwin, \& Hastuti, 2013: 156). According to Dimyati, Herwin, \& Hastuti (2013: 156), the results of a study of the sport of football found several psychological characteristics that young athletes need to possess, such as control of the level of arousal (arousal), high self-confidence, high focus on tasks and capacity to appear energetic.

Research conducted by Schure, (in Dimyati, Herwin, \& Hastuti, 2013: 156) clearly shows that the personality profile of team sports athletes is different from individual sports athletes, especially between athletes who play in team sports that are direct 
interaction (eg basketball) and indirect interactions (eg volleyball). In general, team sports athletes are more anxious, dependent, open, and alert, but less sensitive and imaginative than individual athletes. Athletes in sports that are directly interacting (eg football), are judged to be more independent and unselfish than athletes from sports that have indirect interactions (eg volleyball). Various kinds of literature show that athletes from one sport will have different characters and personality types compared to athletes from other sports (Cox, 2002 in Dimyati, Herwin, \& Hastuti, 2013: 156).

However, different results were found that were contrary to those of the researchers in this study. An example is a study by Nia \& Besharat (2010: 808-812) which did not find significant differences between elite, non-elite athletes, entertainment groups, and non-athletes in extraversion (the attitude or personality type of a person whose interests are more directed towards the outside and social phenomena rather than to himself and his own experience). Davis (2005: 689-694) also revealed the reasons why there was no difference, namely that top-level athletes need to train for hours and regularly to achieve success in competition. This means that for novice athletes or those who do not have competitive experience, there may be differences. However, for athletes who are mature and experienced, both individual and team sports athletes, are generally able to control themselves so that they can appear more relaxed, calm, not emotional, feel safe, and so on.

\section{Conclusion}

Knowing the results of the research and the results of data analysis that has been carried out, the conclusions obtained are as follows. (1) There are significant differences related to the mental toughness of PON DIY athletes based on each sport. The mental toughness of Pencak silat and kite flying was found to be better than other sports. (2) There is a significant difference in the mental toughness of DIY PON athletes based on individual and team sports. The mental toughness of individual sports PON DIY athletes was found to be better than team sports.

\section{Conflict of Interest Statement}

The authors declare there is no conflicts of interests.

\section{About the Authors}

Anas Ardiansyah, Undergraduate studies at STKIP Taman Siswa Bima, and took the Master's Program in the Department of Sport Science, Yogyakarta State University. His research topics are related to sports education.

Prof. Dr. Dimyati, M.Si, is a Professor in the Department of Sports Education, Faculty of Sports Science, Yogyakarta State University. The field of expertise is educational psychology. 


\section{References}

Algani, P., Yuniardi, M. S., \& Masturah, A. N. (2018). Mental toughness dan competitive anxiety pada atlet bola voli. Jurnal Ilmiah Psikologi Terapan, 6(1), 93-101.

Budiwanto (2017). Metode statistika untuk mengolah data keolahragaan. Malang: UNM Pres.

Cowden, R., G. (2017). On the mental toughness of self-aware athletes: Evidence from competitive tennis players. South African Journal of Science, 113(1-2), 50-56.

Dimyati, Herwin, \& Hastuti, T. A. (2013). Karakteristik psikologis atlet di Pusat Pendidikan dan Latihan Pelajar (PPLP). Jurnal Psikologi, 40, 2, 143 - 158.

Dimyati (2018). Psikologi olahraga. Yogyakarta: UNY Press.

Drinkwater, K., Dagnall, N., Denovan, A., \& Parker, A. (2019). The moderating effect of mental toughness: perception of risk and belief in the paranormal. Psychological reports, 122(1), 268-287.

Freitas, S., Dias, C., \& Fonseca, A. (2013). What do coaches think about psychological skills training in soccer? a study with coaches of elite portuguese teams. International Journal of Sports Science, 3(3), 81-91.

Golby, J., \& Sheard, M. (2004). Mental toughness and hardiness at different levels of rugby league. Personality and individual differences, 37(5), 933-942.

Hardiansyah, Y., \& Masturah, A. N. (2019). Ketangguhan mental atlet basket SMA yang mengikuti detection basketball league. Intuisi: Jurnal Psikologi Ilmiah, 11(3), 238244.

Ilyasi, G., \& Salehian, M. H. (2011). Comparison of personality traits between individual and team athletes. Middle-East Journal of Scientific Research, 9 (4), 527-530.

Jones, G. (2002). What is this thing called mental toughness? An investigation of elite sport performers. Journal of applied sport psychology, 14(3), 205-218.

Jones, G., Hanton, S., \& Connaughton, D. (2007). A framework of mental toughness in the world's best performers. The sport psychologist journal, 21(2), 243-246.

Kalinin, R., Balazsi, R., \& Pentek, I. (2019). Relationship between competitive anxiety and mental toughness: a latent regression analysis. Health, Sports $\mathcal{E}$ Rehabilitation Medicine, 20(2), 70-74.

Khoirunnisa \& Jannah, M. (2014). Hubungan antara regulasi emosi dan konsentrasi terhadap resiliensi pada atlet renang. Character, 3(2).

Lopez, A. V., \& Juan, M. V. T. (2015). Mental toughness of scholar athletes. Journal of Arts, Science \& Commerce, 3(1), 22-32.

Murdiansyah (2015). Perbedaan kepribadian antara atlet individual dan atlet berkelompok. Dewantara, 1(2).

Newland, A., Newton, M., Finch, L., Harbke, C. R., \& Podlog, L. (2013). Moderating variables in the relationship between mental toughness and performance in basketball. Journal of sport and health science, 2(3), 184-192.

Nia, M., \& Besharat, M. A. (2010). Comparison of athlete's personality characteristics in individual and team sports. Publishing $\mathcal{E}$ Printing International Journal (US Published), 12 (5), 808-812. 
Nopiyanto, Y. E., Dimyati, D., \& Dongoran, F. (2019). Karakteristik psikologis atlet sea games indonesia ditinjau dari cabang olahraga tim. Sporta Saintika, 4(2), 27-46.

Nugraha, D. Y., Salman, R. S., Pratama, B., Al Fayed, M. G., Ikhram, A., Bahrun, M. I., ... \& Nurlifiana, S. (2020). The mediating effect of motivation and competitive experience variables on the effect of mental toughness and competitive anxiety on athletes. ACTIVE: Journal of Physical Education, Sport, Health and Recreation, 9(2), 122-130.

Ramadhan, S., Mardapi, D., Sahabuddin, C., \& Sumiharsono, R. (2019). The estimation of standard error measurement of Physics final examination at senior high schools in Bima Regency Indonesia. Universal Journal of Educational Research, 7(7), 15901594.

Raynadi, F. B., Rachmah, D. N., \& Akbar, S. M. (2016). Hubungan ketangguhan mental dengan kecemasan bertanding pada atlet pencak silat di Banjarbaru. Jurnal Escopy, 3(3), 149-154.

Retnoningsasy \& Jannah, M. (2020). Hubungan antara mental toughness dengan kecemasan olahraga pada atlet badminton. Character: Jurnal Penelitian Psikologi, $7(3)$.

Romas, M. Z. (2019, October). Profil peran psikologi olahraga dalam meningkatkan prestasi atlet di Serang-Banten Menuju Jawara. In Prosiding Seminar Nasional IPTEK Olahraga (SENALOG), 2(1).

Ruparel, N. (2020). Mental toughness: Promising new paradigms for the workplace. Cogent Psychology, 7(1), 1722354.

Sajjan, M. (2018). Mental toughness among Athletes: A comparative study. International Journal of Applied Research, 4(2), 157-161.

Setiawan, E., Patah, I. A., Bapista, C., Winarno, M. E., Sabino, B., \& Amalia, E. F. (2020). Self-efficacy dan mental toughness: Faktor psikologis berkorelasi dengan performa atlet. Jurnal Keolahragaan, 8(2).

Sinulingga, A., \& Hardinoto, N. (2014). Perbedaan karakter olahraga kompetitif (studi komparatif: olahraga individu dan olahraga tim). Pertemuan Ilmiah Ilmu Keolahragaan Nasional 2014 Penerapan IPTEK dan Penguatan Ilmu Keolahragaan dalam Mendukung Prestasi Olahraga Nasional, 10-12 Oktober 2014.

Sukadiyanto (2006). Perbedaan reaksi emosional antara olahragawan body contact dan non body contact. Jurnal Psikologi, 33(1), 50-62.

Suprapto, E. (2020). The Analysis of Instrument Quality to Measure the Students' Higher Order Thinking Skill in Physics Learning. Journal of Turkish Science Education, $17(4), 520-527$. 

be applied to their work. Under the terms of this license, no permission is required from the author(s) or publisher for members of the community to copy, distribute, transmit or adapt the article content, providing a proper, prominent and unambiguous attribution to the authors in a manner that makes clear that the materials are being reused under permission of a Creative Commons License. Views, opinions and conclusions expressed in this research article are views, opinions and conclusions of the author(s). Open Access Publishing Group and European Journal of Physical Education and Sport Science shall not be responsible or answerable for any loss, damage or liability caused in relation to/arising out of conflict of interests, copyright violations and inappropriate or inaccurate use of any kind content related or integrated on the research work. All the published works are meeting the Open Access Publishing requirements and can be freely accessed, shared, modified, distributed and used in educational, commercial and non-commercial purposes under a Creative Commons attribution 4.0 International License (CC BY 4.0). 